\title{
Notes on nomenclature and typification of Heteropogon fischerianus and $H$. contortus var. distichus (Poaceae)
}

\author{
Kumar A. ${ }^{1}$, Chakrabarty T. ${ }^{2}$, Bandyopadhyay S. ${ }^{3} \&$ A. Bhattacharjee ${ }^{1^{*}}$ \\ ${ }^{1}$ Central National Herbarium, Botanical Survey of India, P.O. Botanic Garden, Howrah, West Bengal - 711 103, India. \\ 24, Botanical Garden Lane, Howrah, West Bengal - 711 103, India. \\ ${ }^{3} 23 F$, Fern Road, Kolkata, West Bengal - 700 019, India. \\ *Email: avibsi@rediffmail.com
}

\begin{abstract}
The authors analyse a confusion in two validly published names, Heteropogon fischerianus and $H$. contortus var. distichus and provide clarifications on their nomenclature and typification.
\end{abstract}

Keywords: Holotype, Lectotype, Synonym.

\section{Introduction}

The genus Heteropogon Pers. includes six species distributed from Europe to tropical and subtropical regions of the World and all of the species are also known from India (Clayton et al., 2020; Drisya \& Pradeep, 2020). Singh et al. (2015) considered $H$. fischerianus Bor, H. polystachyus (Roxb.) Schult. and H. ritchiei (Hook. f.) Blatt. \& McCann as endemic to India, overlooking the occurrence of $\mathrm{H}$. ritchiei in Myanmar (Kress et al., 2003). Further, Clayton et al. (2020) treated H. polystachyus as a heterotypic synonym of $H$. contortus which has a wide distribution. Therefore, in India the only endemic species in the genus is $H$. fischerianus which is confined to Andhra Pradesh, Karnataka, Kerala, Tamil Nadu and Telangana (Siddabathula et al., 2020).

Deshpande (1988) revised Heteropogon in India and treated H. contortus (L.) P.Beauv. ex Roem. \& Schult. var. distichus C.E.C.Fisch. ('distichous') as a synonym of $H$. fischerianus as had Bor (1951) in describing $H$. fischerianus. Deshpande (1988) also cited the type as “Type: India: Kodaikanal, Pulneys, Jesmond hill, Bourne 2025, July 1, 1901 (K), (Isotype, CAL!);

Received: 06.05.2020; Revised \& Accepted: 25.09.2020

Published Online: 30.09.2020
Kodaikanal, Pulneys, Bourne 2026, July 1, 1901 (Paratype CAL! Photo MH!); Poonachi, Annamalais, C.A. Barber, Oct. 10, 1901 (Paratype, MH Photo!)". This includes the types of two validly published names, $H$. fischerianus and $H$. contortus var. distichus, of which Bourne 2025 was designated as holotype of H. fischerianus by Bor (1951) and Bourne 2026 was selected as lectotype of $H$. contortus var. distichus by Siddabathula et al. (2020). Siddabathula et al. (2020) recently treated $H$. fischerianus as a new name for $H$. contortus var. distichus and stated "Bor (1951) described Heteropogon fischerianus as new species and treated H. contortus var. distichus C.E.C. Fisch. as synonym of his new species. However, as per the ICN (Turland et al., 2018) the name $H$. fischerianus Bor should be treated as a new name (nom. nov.) for H. contortus var. distichus C.E.C.Fisch.”. However, this statement is erroneous because there is nothing in the ICN that requires Bor to have treated $H$. fischerianus as a new name according to Art. 6.11 (Turland et al., 2018). Bor (1951) did not propose $H$. fischerianus as a substitute for $H$. contortus var. distichus; rather he described it as a new species (at different rank). Thus, $H$. fischerianus is not a replacement name or new name of $H$. contortus var. distichus as it is not validated solely by reference to H. contortus var. distichus. As per Art. 6.13 of the ICN (Turland et al., 2018), H. fischerianus is the name of a new taxon described by Bor.

Heteropogon contortus var. distichus was validly described by Fischer (1934) who cited "Anamallais at 3,500 ft. (Barber); Kodaikanal, 6,000-7,000 ft. (Bourne)" as the basis for the name (i.e. the original 
material), but did not designate a type as it was not required then. Later, Bor (1951: 170) described $H$. fischerianus as a new species and cited "IND. OR.: Madras, Kodaikanal, Pulneys, 'Fairy Falls', 27 Apr. 1898, Bourne 1207; 'Jesmond Hill', 1 Jul. 1901, ibid. 2025 (typus in Herb. Kew.); ibid. 2026; Poonachi, Annamalais, 10 Oct. 1901, C. A. Barber" in the protologue. He also stated "This very distinct and remarkable species of Heteropogon was considered by Fischer to be merely a variety of Heteropogon contortus (Linn.) P.Beauv. to which he gave the name var. distichus C.E.C.Fischer. The habit of the species is, however, so unique and, moreover, the spikelets smaller than those of Heteropogon contortus, that there is no doubt that this plant merits specific rank". Although Bor (1951) could have adopted the epithet 'distichus' used at varietal rank by Fischer, he had no obligation either to adopt Fischer's epithet or to typify his name by an element available to Fischer according to Art. 11.2 (Turland et al., 2018); instead of adopting 'distichus' he commemorated Fischer in the name of his new species, but he did in fact typify it by a specimen of one of the collections (2025 at K) cited by Fischer.

Bor (1951) had three options when publishing this new species: 1). Describing the species as new (Art. 6.9), in which case it would be normal, but not obligatory, to adopt a different epithet from that of the variety. As such its publication would require to satisfy all the requirements for valid publication of the name of a new species (see esp. Art. 38-40), including, after 1957, indication of type; 2). Publish a new combination based on Heteropogon contortus var. distichus (Art. 6.10). This would require the species to be called "H. distichus (C.E.C.Fisch.) Bor" and would necessitate to satisfy the requirements for valid publication of the name of a new combination (see esp. Art. 41). It would necessarily be typified by the type of its basionym (the varietal name) (Art. 7.3) regardless of the elements to which the later author applied it; 3). Publish a replacement name ("avowed substitute") with $H$. contortus var. distichus as its replaced synonym (Art. 6.11); this would necessarily have a different epithet from that of the variety but would necessarily be typified by the type of its replaced synonym (the varietal name)
(Art. 7.3) regardless of the elements to which the later author applied it. It would also have to meet the requirements of Art. 41.

Among the above three options, the first option was chosen by Bor (1951). Moreover, Bor (1951) included "all [the] syntypes under Art. 9.6" of $H$. contortus var. distichus, but no type of H. contortus var. distichus C.E.C.Fisch. had been designated in 1951. As Bor (1951) had published a new species and "a name has no priority outside the rank at which it is published" (Art. 11.2), the name was validly published as a new species as he provided a Latin diagnosis (and description). He also indicated the type although that only became mandatory from 1958 onwards. If Bor had been publishing the name of a new variety and used the epithet 'fischerianus', that name would have been superfluous and illegitimate according to Art. 52.2(a), but, for a species name, $H$. contortus var. distichus was not "a name ... of which the epithet ought to have been adopted [by Bor], under the rules" (Art. 52.1) (Turland et al., 2018).

\section{Notes on typification}

There are four specimens of Bourne 2025, one each at CAL, G, K, US; three specimens of Bourne 2026 are at CAL, K, MH (one each); two specimens of Barber 3719 are at FRC, MH (one each). As Bor (1951) cited only Bourne 2025 (K) as type in the protologue and there is a single specimen belonging to this collection at K, Bourne $2025(\mathrm{~K})$ is the holotype of Heteropogon fischerianus and duplicates of this number are isotypes while the remaining cited specimens are paratypes of this name.

Siddabathula et al. (2020) treated Heteropogon fischerianus as a new name for $H$. contortus var. distichus which is erroneous and cited "Lectotype (designated here): India, Tamil Nadu, Kodaikanal, Pulneys (Palani), Jesmond hill, 1 July 1901, Bourne 2026 (K000245942!; isolectotypes CAL!, MH00002609!)". Therefore, though they intended to typify $H$. fischerianus, actually they appear to have published an effective lectotypification of $H$. contortus var. distichus. Therefore, it has been concluded that the holotype of $H$. fischerianus is one 
of the syntypes of $H$. contortus var. distichus. Both names, $H$. fischerianus and $H$. contortus var. distichus are validly published as a new species and a new variety respectively; the former having been typified (holotype) with Bourne 2025 (K000245941) by Bor while describing the species, and the latter with Bourne 2026 (K000245942) as lectotype by Siddabathula et al. (2020). Though Deshpande (1988) already treated H. contortus var. distichus as a synonym of $H$. fischerianus, Siddabathula et al.'s (2020) choice of one of the syntypes, Bourne 2026 as the lectotype of H. contortus var. distichus, precisely makes $H$. contortus var. distichus a heterotypic synonym (not homotypic) of $H$. fischerianus.

\section{Taxonomic treatment}

Heteropogon fischerianus Bor, Kew Bull. 6: 170. 1951. Type: INDIA, Tamil Nadu, Kodaikanal, Pulneys, Jesmond hill, 01.07.1901, Bourne 2025 (holo K [K000245941 digital image!]; iso CAL [CAL0000002320!], G [G00165923 digital image!], US [US00132611 image!]). INDIA, Tamil Nadu, Kodaikanal, Pulneys, Jesmond hill, 01.07.1901, Bourne 2026 (para K [K000245942 digital image!], CAL [CAL0000002306!], MH [MH00002609 n.v.]); Poonachi, Annamalais, 10.10.1901, C.A. Barber 3719 (para FRC n.v., MH [MH00002608 n.v.]). Image of holotype available at: http:// specimens.kew.org/herbarium/K000245941

H. contortus (L.) P.Beauv. ex Roem. \& Schult. var. distichus C.E.C.Fisch. in Gamble, Fl. Madras 3: 1743 1934. Lectotype (designated by Siddabathula et al., 2020): INDIA, Tamil Nadu, Kodaikanal, Pulneys, Jesmond hill, 01.07.1901, Bourne 2026 (K [K000245942 digital image!]); isolecto CAL [CAL0000002306!], MH [MH00002609 n.v.]). Residual syntypes: INDIA, Tamil Nadu, Kodaikanal, Pulneys, Jesmond hill, 01.07.1901, Bourne 2025 (CAL [CAL0000002320!), G [G00165923 digital image!], K [K000245941 digital image!], US [US00132611 digital image!]); Poonachi, Annamalais, 10.10.1901, C.A. Barber 3719 (FRC n.v., MH [MH00002608 n.v.]). Image of lectotype available at: http://specimens.kew.org/ herbarium/K000245942

\section{Acknowledgements}

The authors are thankful to Dr. A.A. Mao, Director, Botanical Survey of India (BSI), Kolkata and Dr. V.P. Prasad, the former Head of Office, Central National Herbarium, BSI, Howrah for the facilities. We are also thankful to Dr. John McNeill (E) for comments, suggestions and critical evaluation of the manuscript.

\section{Literature Cited}

BOR N.L. 1951. Some new species of Indian grasses. Kew Bulletin 6: 166-171.

CLAYTON W.D., GOVAERTS R., HARMAN K.T., WILLIAMSON H. \& M. VORONTSOVA 2020. World Checklist of Poaceae. Facilitated by the Royal Botanic Gardens, Kew. Available at: http://wcsp.science.kew.org/ (Accessed on 23.04.2020).

DESHPANDE U.R. 1988. The genus Heteropogon Pers. (Poaceae) in India. Bulletin of the Botanical Survey of India 50: 120-125.

DRISYA V. \& A.K. PRADEEP 2020. On reinstating Heteropogon allionii (Poaceae: Panicoideae). Phytotaxa 429: 157-166. https://doi.org/10.11646/phytotaxa.429.2.6

FISCHER C.E.C. 1934. Heteropogon contortus var. distichus. In: GAMBLE J.S. (ed.), Flora of the Presidency of Madras. Volume 3(10). Adlard \& Son Ltd., London. pp. 17421743.

KRESS W.J., DEFILIPPS R.A., FARR E. \& D.Y.Y. KYI 2003. A checklist of the trees, shrubs, herbs and climbers of Myanmar (Revised from the original works by J.H. Lace and H.G. Hundley). Contributions from the United States National Herbarium 45: 1-590.

SIDDABATHULA N., ARIGELA R.K., SINGH R.K. \& L. PARAMESH 2020. The endemic tanglehead grass Heteropogon fischerianus Bor and the giant speargrass Heteropogon triticeus (R. Br.) Stapf ex Craib, new records for the flora of Telangana state, India. NeBIO 11: 1-6.

SINGH P., KARTHIGEYAN K., LAKSHMINARASIMHAN P. \& S.S. DASH 2015. Endemic vascular plants of India. Botanical Survey of India, Kolkata.

TURLAND N.J., WIERSEMA J.H., BARRIE F.R., GREUTER W., HAWKSWORTHD.L., HERENDEEN P.S., KNAPP S., KUSBER W.-H., LI D.-Z., MARHOLD K., MAY T.W., MCNEILL J., MONRO A.M., PRADO J., PRICE M.J. \& G.F. SMITH (eds.) 2018. International Code of Nomenclature for algae, fungi, and plants (Shenzhen Code) adopted by the Nineteenth International Botanical Congress Shenzhen, China, July 2017. Regnum Vegetabile 159. Koeltz Botanical Books, Glashütten. https://doi.org/ 10.12705/Code.2018. 